\title{
Some Thoughts on Becoming A Great Teacher...
}

\author{
Reddy KR \\ Professor \& Head \\ Microbiology Department \\ Gandaki Medical College \& Teaching Hospital, Pokhara, Nepal
}

A mediocre teacher tells

A good teacher explains

A superior teacher demonstrates

A great teacher inspires.

Journal of

GANDAKI

MEDICAL

COLLEGE-

NEPAL

\section{(J-GMC-N)}

J-GMC-N | Volume $\mathbf{0 9}$ | Issue $\mathbf{0 2}$ July-December $\mathbf{2 0 1 6}$
Are teachers born? or

Are teachers made?

Can teaching be taught?

What is your religion?

When I do good, I feel good.

When I do bad, I feel bad.

That's my religion.

Please spare some time to reflect on these thoughts...

A great teacher is like a candle - it consumes itself to a light the way for others.

The best teachers teach from the heart, not from the book. Teaching is the highest form of understanding. Teaching is the profession that teaches all the other professions (Fig 1).

Fig 1: A great teacher

Actor

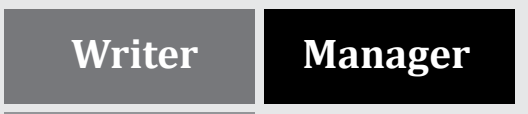

\section{Developer}

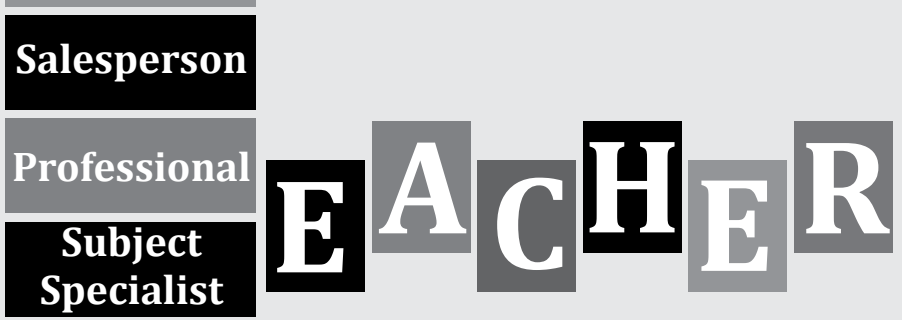

Teaching is an art, to be perfected. Teaching is not a lost art, but the regard for it is a lost tradition.

The curriculum is so much necessary raw material, but warmth is the vital element for the soul of the student. 
The task of the excellent teacher is to stimulate "apparently ordinary" people to unusual effort. The tough problem is not in identifying winners: It is in making winners out of ordinary people. Don't try to fix the students, fix ourselves first. A good teacher makes the poor student good and the good student superior. When our students fail, we, as teachers, too, have failed. A great teacher is a master of simplification and an enemy of simplism.

Who dares to teach must never cease to learn. To teach is to learn twice (Fig 2).

Fig 2: To teach is to learn twice

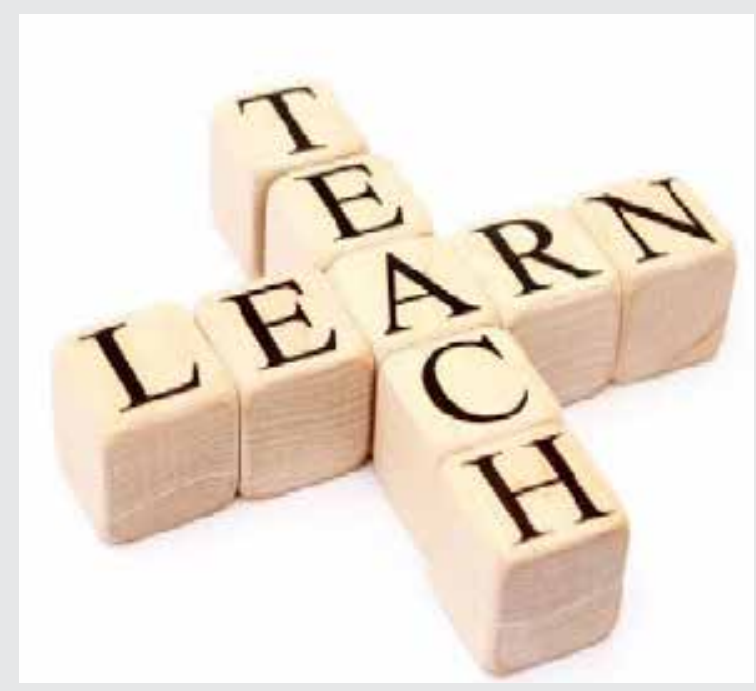

The art of the teaching is the art of assisting discovery. Professors known as outstanding teachers do two things; they use a simple plan and many examples.

Teachers are expected to reach unattainable goals with inadequate tools. The miracle is that at times they accomplish this impossible task.

Teaching should be full of ideas instead of being stuffed with facts. I like a teacher who gives me something to take home and think about rather than an assignment or test. The object of teaching a pupil is to enable him/her to get along independently without his teacher/ parents/ elders support.

The dream begins with a teacher who believes in students, who tugs and pushes and leads you to the next plateau, sometimes poking the students with a sharp stick called "truth".

In teaching you cannot see the fruit of a day's work. It is invisible and remains so, may be for twenty years.

The true teacher defends his/her students against his own personal influence. He inspires self-distrust. He guides their eyes from himself/herself to the spirit that quickens him/her.

The best teacher is the one who suggests rather than dogmatizes, and inspires his/her listener with the wish to teach himself/herself.

A teacher's purpose is not to create students in his own image, but to develop students who can create their own image.

Teaching is leaving a vestige of oneself in the development of another. And surely the student is a bank where you can deposit your most precious treasures.

"The teacher who is indeed wise does not bid you to enter the house of his wisdom but rather leads you to the threshold of your mind" - Kahlil Gibran 
Fig 3: Students' expectations from teachers

\begin{tabular}{|cc|}
\hline - is kind & - tell us how we are doing \\
- listen to us & - allows us to have our say \\
- is generous & - doesn't give up on us \\
- has faith in us & - cares for our opinion \\
- encourages us & - makes us feel clever \\
- keeps confidence & - makes allowances \\
- takes time to explain & - treats us equally \\
- likes teaching students & - stands up for us \\
- helps when we are stuck & - tells the truth \\
- likes teaching the subject & - is forgiving \\
\hline
\end{tabular}

Fig 4: ABCs for great teachers

\begin{tabular}{|lll|}
\hline Adventurous & Enthusiastic & Open-minded \\
Ambitious & Friendly & Organised \\
Bright & Gifted & Polite \\
Cheerful & Healthy & Punctual \\
Clean & Humane & Quick-witted \\
Confident & Humorous & Resourceful \\
Cooperative & Industrious & Sociable \\
Creative & Intelligent & Talented \\
Critical & Joyous & Unbiased \\
Dependable & Kind & Visionary \\
Democratic & Levelheaded & Well-informed \\
Eloquent & Magnanimous & Youthful \\
Energetic & Noble & Zealous \\
& & \\
\hline
\end{tabular}

Fig 5: Qualities of a great teacher

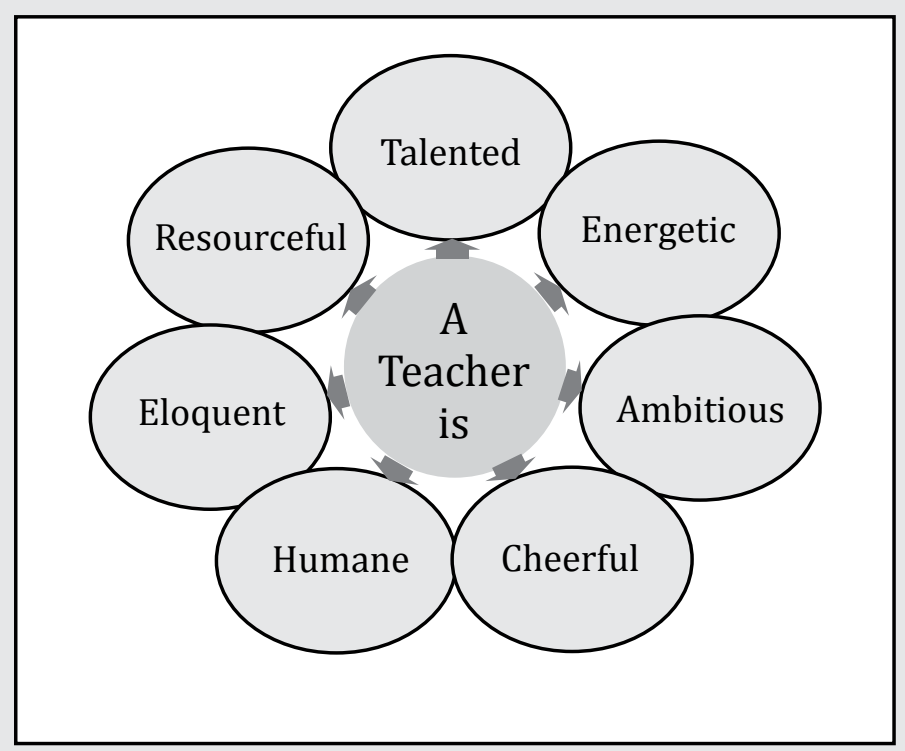


Fig 6: Qualities of a great teacher

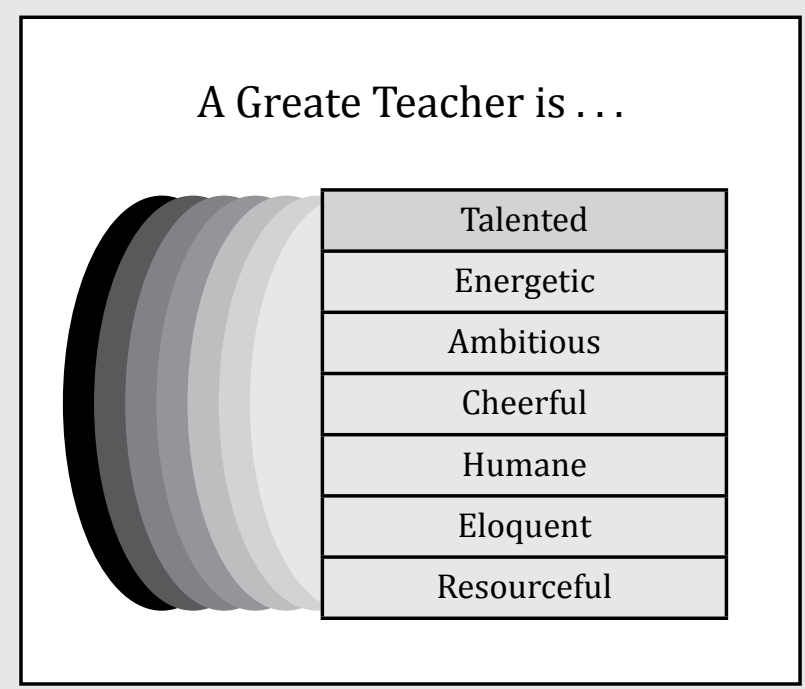

\section{TALENTED}

A great teacher is trained, adept, learned, equipped, never ending learner, and takes questions. A great teacher learns. Teaching is a dynamic skill, needs regular retraining and refreshing. A great teacher will have a command of subject-specific knowledge, listens to what students tell and takes feedback and read body language of students'. A great teacher gets into his subject, gets the subject into students' hearts and mind. A great teacher structures his teaching and tells what he wants to tell and tells what he has told.

\begin{tabular}{|l|}
\hline Trained \\
\hline Adept \\
\hline Learned \\
\hline Equipped \\
\hline Never ending learner \\
\hline Takes questions \\
\hline
\end{tabular}

\section{ENERGETIC}

A great teacher is healthy, attentive, lively, and enthusiastic. A great teacher displays an energetic body language with active movement, good eye contact, good posture, impressive pace, encouraging gestures, and visually vibrant.

A great teacher is enthusiastic to teach about the subject with the students. A good teacher is confident and possesses a passion for subject, rehearse, shun shyness, imagine success, and calm down.

"What the teacher is, is more important than what he teaches" - Karl Meninnger. 


\begin{tabular}{|l|}
\hline Healthy \\
\hline Attentive \\
\hline Lively \\
\hline Enthusiastic \\
\hline
\end{tabular}

\begin{tabular}{|l|}
\hline Calm down \\
\hline Rehearse \\
\hline Imagine success \\
\hline Shun shyness \\
\hline Passion for subject \\
\hline
\end{tabular}

\section{AMBITIOUS}

A great teacher aims big, challenges himself and strives for success. Success comes from a desire, decision and determination. Effective teachers try and try and try and let students know they try. Determination, energy, and courage appear spontaneously when we care deeply about something.

A great teacher is positive, possesses passion to inspire, urge to help, right attitude and expect good. A teacher who inspire, know that teaching is like cultivating a garden, and those who would have nothing to do with thorns must never attempt to gather flowers. Teachers who inspire realize there will always be rocks in the road ahead of us. They will be stumbling blocks or stepping stones; it all depends on how we use them. A great teacher takes risks. If there is no chance of failure, then success is meaningless.

"A teacher attains eternity; he can never tell where his influence stops" - Henry Brooks Adams.

\begin{tabular}{|l|}
\hline Passion to inspire \\
\hline Urge to help \\
\hline Right attitude \\
\hline Expect Good \\
\hline
\end{tabular}

A teacher who is attempting to teach without inspiring the pupil with a desire to learn is hammering on cold iron (Regarded as bad teacher).

\section{Good teachers are costly but bad teachers cost more}

\section{CHEERFUL}

A great teacher is cheerful: Smiling, hygienic, optimistic, and well dressed. A great teacher will be having a pleasing personality: Displays smile, mention name, takes interest, listen, and empathize with students. It is hard for people to disagree with you when you are smiling.

A great teacher is humerous: Socially lubricant, enhances communication, makes class enjoyable, helps you see the joy in life, and no saracasm. 


\section{HUMANE}

A great teacher is humane: Compassionate, understanding, fair, supportive, and friendly. A great teacher is supportive and when students really have something important to say, they should be able to say it clearly, forcefully, and with proper evidence. A great teacher is fair and assesses students based on performance not personality.

"One looks back with appreciation to the brilliant teachers, but with gratitude to those who touched our human feelings"-Carl Jung.

\section{ELOQUENT}

A great teacher is fluent, pleasant, communicative, expressive, and speaks clearly, listen keenly, mind his/her words and tone, maintain eye contact, and courteous. A great teacher supports what he says with examples, statistics, definitions, and testimony.

\begin{tabular}{|l|}
\hline A great teacher REACHes \\
\hline Reinforce \\
\hline Encourage \\
\hline Acknowledge \\
\hline Clarify \\
\hline Highlight \\
\hline
\end{tabular}

\begin{tabular}{|l|}
\hline $\begin{array}{l}\text { A great teacher's VOICE } \\
\text { (Visual, auditory, olfactory, kines- } \\
\text { thetic domains) }\end{array}$ \\
\hline Vocabulary \\
\hline Order of words \\
\hline Intonation \\
\hline Cut of the unwanted \\
\hline Empower \\
\hline
\end{tabular}

\section{RESOURCEFUL}

A great teacher is creative, original, imaginative, intelligent, sensible, and inspiring. A great teacher keep cool, resist being provoked, establish rapport, judicious discipline, praise liberally and that's how manages his class and students.

A great teacher has commonsense: Assess situations quickly, make appropriate decisions, know what to ignore, when to react, and be pro-active.

"It is the supreme art of the teacher to awaken joy in creative expression and knowledge" - Albert Einstein.

The teaching is a passion to change the world, A better place to live for the future generations.

Practice, Practice, Practice...

You will attain your GOAL. 